\title{
Translation in Odia: A Historical Survey
}

\section{Aditya Kumar Panda}

\begin{abstract}
History of translation in Odia could be studied either by surveying the major translated works in Odia chronologically or by reflecting on the development of Odia literature through translation socioculturally and politically, although both the approaches are not mutually exclusive. Translation is central to the development of Odia literature like that of any modern Indian literature. If one goes through the history of Odia literature, one can find that the quantum of Odia literature is more through translation. This essay deals with the historical account of the translation into Odia.
\end{abstract}

Keyword: History, Odia, translation, adaptation, transcreation,

\section{Introduction:}

Every history has an oral tradition of which a complete record does not exist. Whatever is recorded becomes the part of a history. A history is never a perfect history. It is biologically impossible on the part of human beings to write a perfect history which should count for each minute of the past. Therefore, history of translation is possible, if there exists written records of translation work in a language. In this historical account, "translation proper (translation of a Source Language text to a target language with fidelity to SL form and meaning)" has not only been taken into account, but also broadly interpretation, retelling, adaptation, transcreation.

\subsection{Periodization:}

A history can be studied by dividing it according to time or place or the medium of writing. Chronologically, History of 
Odia translation could be classified into 5 periods. They are:
A. Age of Pre-Sarala and Sarala (till 15th century)
B. Age of Panchasakhaa and Bhanja (from 16th to 18th century)
C. The Colonial Age (19th to mid-20th century)
D. Age of Satyabadi and Pragatibaadee and Early 20th Century (upto 1947)
E. Modern Age (20th to 21st century)

But these five chronological periods could also be classified under two categories by considering the medium of writing: 1. Palm leaf tradition (from pre-Sarala to till the beginning of the Colonial period), 2 . Print (technology) tradition (from the colonial period to till date). Although there is a period before palm leaf tradition which can be called as inscription literature period (from $300 \mathrm{BC}$ to $1500 \mathrm{AD}$ ), but the recorded inscription reveals that those were not of translation. Another division can be made on the basis of types of translation in the history of Odia language. One will be counting the literary translation which includes mythological, religious translation and another could be nonliterary translation which includes the texts related to the domain of Astrology, Astronomy, Mathematics, Medicine, Economics etc. Based on the collected 40,000 palm leaf manuscripts in the Odisha State Museum, it is found that there were writings on Veda, Tantra, Jyotisha, Dharmasastra, Ayurveda, Ganita, Silpasastra, Samgita, Abhidhana, Vyakarana, Sanskrit Purana, Sanskrit Kavya, Alamkara etc.

\section{Age of Pre-Sarala and Sarala (till $15^{\text {th }}$ century)}

History of translation in Odia before $18^{\text {th }}$ century could be perceived through retelling, adaptation, transcreation more than that of translation proper. Translation was recognized as a writing. It is nowhere written in Sarala Mahabharata that Sarala translated the Mahabharata but it has been written that it is a writing done 
by Sarala Das (it is Shudramuni Sarala Dasnka Kruta Mahabharata in Odia). Translation as it is grounded in $19^{\text {th }}$ and $20^{\text {th }}$ century as a faithful rendering of a source text in a target language seems to be an approach imported to India. Before $19^{\text {th }}$ and $20^{\text {th }}$ century, translation was a writing in India (as it is evident from Sarala Das's Mahabharata). There was no demarcation between the original text and the translated one. It was not classified as a separate domain as it is at present. As far as the earliest record goes, the History of Odia Translation dates back to 15 th century when Sarala Das wrote Odia Mahabharata.

There was an oral tradition which contributed to the early development of Odia literature of which no written record exists. Sanskrit was the dominant language at that time. The earliest record of history of translation in Odia reveals that the available literature in Odisha was in Sanskrit and Sanskrit literature gave an impetus to the development of early Odia literature. The kings and the pundits were giving importance to Sanskrit literature and Odia was considered as the language of shudras (untouchables). The Brahmins had the access to Sanskrit literature. It was in this period, the First Poet (Aadikavi) Sarala Das was born and all his talents were for creating Odia literature and establishing Odia language through transcreation. At the time of reign of Kapilendra Dev, Sarala Das, a non-Brahmin, thought to recreate Mahabharata that would be meant for all. And he thought that the language of the pundits should not be the language of this Mahabharata. Therefore, he added many colloquial Odia words in his retelling of Mahabharata. Sarala Das's Mahabharata was to democratize the restricted domain of knowledge. He could have created a new writing instead of retelling the Sanskrit Mahabharata, but he took the available source text and created a parallel Odia text to bridge the gap between the Brahmins and non-Brahmins. This Mahabharata cannot be considered as a translation proper, but it qualifies to be included as the earliest translation that established Odia literature. Why should it be considered under translation is that it has a Source Text, events and proper names are also from the Source, the main story and theme are also from a source. While 
translating Mahabharata, he used the technique of additions and deletions and adaptation.

\section{Age of Panchasakhaa and Bhanja Yuga (from $16^{\text {th }}$ to $18^{\text {th }}$ century)}

Next phase of translation could be seen in the literature of Panchasakhaa Yuga. Panchasakhaa Yuga includes the writings of five Odia poets during the late $15^{\text {th }}$ and $16^{\text {th }}$ centuries: Balaram Das, Atibadi Jagannath Das, Achyutananda Das, Ananta Das and Jasobanta Das. They are considered as the pioneers of Utkaliya Vaishnavism and they were also influenced by Jay Dev's Gita Govinda. Balaram Das did a free translation of Valmiki's Ramayana and entitled it as Jagamohan Ramayana. "In the Jagamohan Ramayana he creates a parallel ideological structure by alternating between breaking with the original text, closely following it and at other times inventing new narratives. This was the third phase of the translation process. (St-Pierre \& Kar, 2007)". The greatest contribution of Panchasakha Yuga to Odia literature through translation is Jagannatha Dasa's Srimad Bhagabata. It is one of the most popular and widely read texts in Odia. Like Sarala Dasa's Mahabharata in Oriya, Srimad Bhagavata of Sri Jagannatha Dasa is not a literal translation of the Sanskrit original. But all the same, the Oriya translation of the Srimad Bhagavata by Sri Jagannatha Dasa is a marvel of creation with its sparkling originality and scintillating clarity (Das \& Sahoo, 2009). Achyutananda is famous as a saint poet of Odisha. Achyutananda Das's Lahari Harivamsa is also a transcreation from the Sanskrit original. According to Mayadhar Mansingh, the Lahari Harivamsa of Achyutananda is an original work retaining only the framework of the Sanskrit model.

Sarala's Mahabharata and Jagannath's Srimad Bhagabata were the literary pieces which were transcreated from the Sanskrit original to be read by the people who had no access to the same texts ritually owned by the Brahmins. These were the attempts to break the closed Sanskritic tradition prevailed at that time in Odisha. Translations from Sarala Das to Jagannath Das were radical attempts at vernacularization and coincided with the founding 
of a powerful Oriya empire by Kapilendra Dev and its subsequent consolidation by his inheritors. The aesthetic evident in these works can be said to mirror the sociopolitical by subverting the dominant pan-Indian Sanskritic-Brahminical hegemony.(The Princeton Encyclopedia of Poetry and Poetics, 2012).

Yashovant Das is popular all over Odisha for his memorable song, "bhajukinaarama". It is a part of his writing Govindachandra Teekaa. He translated the Sanskrit "Swarodayalesha" into Odia and named it 'Shiva swarodaya'. It is not a translation proper but an adaptation in Odia.

Sixteenth century poets also translated the Gita Govinda into musical Odia. Dharanidhar, Brindaban and Trilochan Das translated the Gita Govinda into Odia. Dharanidhar translated it in his navakiyaani form (9 syllables) and Brindaban translated it with Odia raga and raginis and Trilochan Das translated and named it as Govindagitaa. (Encyclopedia of Indian Literature, Sahitya Akademi, 1988)

Translation activity also flourished in seventeenthcentury Odisha: Mukul Das translated Betala Panchavinsati, and a portion of Rupa Goswami's Bidagdha Madhaba was translated by the poet Gopalakrishna Patnaik. Other notable translations of that period include Krishna Singh's Mahabharata, Haladhara Das's Adhyatma Bhagabata, Balabhadra Mangaraj's Kshetra Mahatmya and Balaram Das's Gita. (Pattanaik, 2002)

Among those who translated Sanskrit puranas in verse form during $17^{\text {th }}$ and $18^{\text {th }}$ centuries, the names of Krishnacharan Pattanaik who translated Bhagabata, Vamana purana, Kalki purana, Ramayana, Jayasingha who translated Bhagavad Gita and Dronaparva of the Mahabharata, Haladhar Pattanaik and Suryamani Chayu pattanaik, translators of Adhyatma Ramayana deserve special mention. (Encyclopedia of Indian Literature, 1988)

All these translations from Sarala Das to $18^{\text {th }}$ century aimed at freeing knowledge from the clutches of Brahmins. 
Many discrepancies which were created by Brahmins on the basis of caste, class, religion were overthrown. Knowledge of Vedas, puranas which was only accessible to elite class became available through translation in a language that common people could comprehend.

\section{The Colonial Age (19 ${ }^{\text {th }}$ to mid-20 ${ }^{\text {th }}$ century) - Technology Period}

Till the advent of the printing press in Odisha, it was the palm leaf tradition which was dominant in writing literature. Printing press came to Odisha in early $19^{\text {th }}$ century. Printing technology started replacing the palm leaf tradition. Missionaries established Odia Mission Press in Cuttack in 1837 to print Odia books. Before this establishment, books were printed in the Serampore Mission Press in Bengal. The Bible was translated into Odia in 1814. J. Carey translated Hebrew poems into Odia in 1814. The Bible was the first printed book and the first printed translation in Odia. The first printed Odia book brought out in 1809 was the New Testament (Srujanika, 2010).The primary aim of the Bible translation and publication was to preach and spread Christianity in Odisha. A. Sutton translated John Bunyan's The Pilgrim's Progress into Odia. During this period, English was the dominant language and it was the language of the English authority. Printing press was another weapon of this authority to reach the masses through multiple copies of the Bible. Lacey and Sutton translated the Jewel Mine of Salvation into Odia in 1827.

The first Odia story book 'Phulamani O Karuna' was written by Rev. Stubbing in 1857. It was a translation of the Bengali book of that time. (Choudhury, Odisha Review, 2013).

In 1866, Cuttack Printing Press was established by the people of Odisha. Many books were published by Viswambar Vidyabhusana, Fakir Mohan Senapati, Bichhanda Patanaik and Govinda Chandra Pattanaik. Gouri Shankar Ray launched the first periodical, Utkala Dipika during this period. Subsequently, many printing presses were established in Cuttack, Bamanda, Ganjam, 
Puri, Baleswar.

Fakir Mohan Senapati, Radhanath Ray and Madhusudan were the great Odia writers at this period whom a great deal of translated literature was attributed. Much of their writings appeared in the last quarter of the $19^{\text {th }}$ century. This was the formative period of the statehood of Odisha. There were attempts by the Bengali elite to suppress Odia as an independent language. But such attempt was discarded and Odia literature was strengthened through translation and original writing by the great Odia writers: Radhanath Ray, Fakir Mohan Senapati and Madhusudan Rao.

Radhanath Ray had the talent of mixing the elements of Sanskrit classics and English classics. He was the one who introduced the blank verse in Odia poetry. This could well be justified in his Meghanathbadha and Usha. The story of Meghanathbadha is based on Vyasa's Mahabharata and presentation is like that of Homer's Iliad or Virgil's Aeneid. He took the elements of Ovid's stories, William Morris's Atlanta's Race and the mythological story of Usha and Aniruddhha. Radhanath also followed Greek mythical stories completely in some of his writings. His Chandrabhaga and Nandikeshwari could be cited as the examples which would be thought up as the imitation of the love affair of Ovid's Apollo and Daphne and The Seylla. Radhanath's most popular literary piece on the line of adaptation/imitation of Greek and English play is Parvati which he wrote in 1890. The plot construction of Aeschylus's Agamemnon (imitation of Homer's Iliad) and Shakespeare's Hamlet could be found in Parvati. The character of Parvati (queen of Utkala) reminds us of Shakespeare's Gertrude (queen of Denmark) and Aeschylus's Chlytemenestra (queen of Argos). Likewise the character of Gangeswar (king of Utkal) could be compared to Agamemnon (king of Argos) and Senior Hamlet (king of Denmark). Koushalya, the princess of Utkal reminds us of Ipheginia, the daughter of Agamemnon. To quote a popular critic, Ratnakar Chaini's appreciation for Radhanath Ray: The monument of poetry which Radhanath has erected, its 
foundation being Sanskrit literature, its bricks and stones are Greek and English literature, its cementing bonds are the history and legends of Orissa. (Chaini, 1984). Radhanath's Italiyajuba and Meghadoot could be considered as translation proper. Italiyajuba is the Odia translation of an English translation of an Italian story. It is a prose piece. Radhanath is the first Odia translator of the Sanskrit classic Meghadoot. Translation of the Meghadoot is a popular work which also became a text book in a vernacular school in Cuttack. Another Odia writer, Radhamohan Gadnaik appreciated his translation of Meghadoot and wrote that Radhanath has achieved no less success in the translation of Meghadoot as he has done in his own poetic creation (Makers of Modern Odisha, 1993). Radhanth wrote Kedar Gouri in 1886. It was an adaptation of Pyramus and Thisbe. In this adaptation, he added the episode of King's dream and building up of a temple.

Late $19^{\text {th }}$ century was the period when the consciousness of Odisha as a nation which has its own language, culture and literature began to emerge. There were attempts to suppress Odia as a unique language. The colonial authority had already started English education. Text books were being written in English and Bangla. During this period, Radhanath Ray, Fakir Mohan Senapati, Madhusudan Rao became influential and wrote translated published books in Odia. In 1866, Fakir Mohan Senapati translated a biography, entitled Jibancharit written by Ishwarchandra Vidyasagar. It was a prescribed text book for scholarship examination. It was a text book which wrote about the scientists like Copernicus, Galileo, Newton and also like William Jones. Fakir Mohan Senapati translated the Ramayana, the Mahabharata and the Chhandogya Upanishad, Srimad Bhagabat Gita, History of India, Khila Haribamsa into Odia. He was translating from Sanskrit classics as well as from Bangla like Ishwarchandra Vidyasagar's Jivan Charita. Sita Banabasa, another text by Vidyasagar was translated by Bichhanda Charan Patnaik.

Madhusudan Rao is another famous Odia writer who is a contemporary to Radhanath and Fakir Mohan. He is famous 
for his Chhabila Madhu Barnabodha (the A.B.C Primer in Odia). He translated Sitabanabaas, Ramabanabaas, Baala Ramayana, Uttara Ramacharita from Sanskrit to Odia. He transcreated William Cowper's The Solitude of Alexander Selkirk in Odia and named it as Nirbaasitara Bilaapa. Nirbaasitara Bilaapa reads like an original poem. There is no reference of Alexander Selkirk in the Odia poem Nirbaasitara Bilaapa. The translation from English to Odia in the late $19^{\text {th }}$ century was initiating a process of cultural empowerment on the part of Odia language and literature in its colonial history (Mohapatra, RJLCS, 2011).

Another popular Odia writer of this period is Ramsankar Ray who wrote 14 plays in Odia and he also authored Soudamini, one of the early Odia novels. Out of his 14 plays, Banabaalaa is an adaptation of Shakespeare's The Tempest. He wrote this play in 1882.

Jaganmohan Lala was a social reformer and another wellknown dramatist. He translated Toynbee's A Sketch of the History of Orissa (1803-1828) into Odia and entitled it as Odisha Vijaya in 1876. He also translated Thomas Parnell's The Hermit into Odia as Bhramabhanjana.

Towards 1870s, many books of general interest were translated. Vidyasagar's Jibancharit which was a translation of Chamber's Biography could be cited as one. Ishwarchandra Vidyasagar's Jibanacharit can be considered as a scientific text, not technically, as it deals with the biographies of many scientists. This is the first biography to be translated into Odia by Fakir Mohan Senapati. A. Sutton authored the first science writing, 'Padartha Bidyasara' in Odia which was published in 1832. It was a text book on natural science. This book was not a translation but it could be seen as an initiative to promote science writing in Odia. In the mid- $19^{\text {th }}$ century, there came a number of Odia periodicals like Prabodh Chandrika where scientific topics in Odia were published. Viswanath Kar's Utkal Sahitya, a periodical, published many scientific articles regularly. There was a science magazine, named Bigyan Darpan from Kolkota, specially dedicated for science 
writing in Odia.

\section{Age of Satyabadi (20 ${ }^{\text {th }}$ century)}

This period is known as Satyabadi yuga in the history of Odia literature as it refers to the establishment of Satyabadi Vanavidyalaya by Gopabandhu Das. Nationalism, social service and social reformation were the main skopos behind the translation of Satyabadi Yuga in Odisha. Along with Gopabandhu, Pandit Nilakantha Das, Godavarisha Mishra and Acharya Harihara were the chief exponents of the school. In the history of translation of this period, these names come as the translators to strengthen Odia literature, nationality and bring empowerment for the women and downtrodden people of Odisha.

Pandit Nilakantha Das (1884-1967) translated Alfred Lord Tennyson's The Princess and Enoch Arden into Odia. As an important promoters of the Satyabadi Vanavidyalaya, he was to remove the social evils prevailed then in Odisha. Victorian period was a period of women empowerment. Nilakantha wanted to motivate women of Odisha and wanted to change the attitude towards Odishan women. This is why he translated The Princess into Odia as Pranayeenee and Enoch Arden as Dasanayak.

Godavarisha Mishra (1886-1956) adapted R.L. Stevenson's Dr. Jekyll and Mr. Hyde as Ghatantara in Odia. He also translated Victor Hugo's Les Miserable as Abhaaginee and Dickens's A Tale of Two Cities as Athara Sa Satara in Odia. Both Nilakantha and Godavarisha's translations cannot be classified under translation proper but adaptations. Another translation Daasatwara Mochana from Washington's Up from Slavery by Godavarisha Mishra is a translation proper.

Acharya Harihar Das (1879-1972), an another influential members of the school, was famous as an English and Mathematics teacher. His Child's Easy First Grammar has been famous for ever. His translation of the Bhagabat Gita is a remarkable translation work. Alexander Dumas's Count of Monty Cristo was adapted by 
Kanhu Charan Mohanty as Baliraja which was published in 1926.

\subsection{Contemporary to the Satyabadi translators or other early $20^{\text {th }}$ century Translation}

The tradition of translation activities in early $20^{\text {th }}$ century Odia was a continuing tradition of Odia translation from Sanskrit and English. Sanskrit classics and English classics became dominant on the translated literature. Many $20^{\text {th }}$ century writers translated from Sanskrit and English. It was William Shakespeare from English and Kalidas from Sanskrit who became the source for many Odia translations. Balakrushna Kar (1887-1963) imitated Shakespeare's King Lear and wrote Shivadasa. Bharatchandra Nayak translated Kalidas's Kumarasambhabam into Odia. Nayak also translated Hiuen Tsang's Visits to India in Odia.

As many of the translators of early $20^{\text {th }}$ century were influenced by Victorian English poets and Scottish novelists, they translated Tennyson, Arnold and Stevenson, Walter Scott and many others. We have already discussed about Nilakantha and Godavarisha who translated Tennyson and Stevenson. Paramananda Acharya (1893-1971) translated Matthew Arnold's Sohrab and Rustum into Odia as Soraabarustam. Radhamohan Gadnayak (1911-2000) also translated Sohrab and Rustum into Odia. Chandrasekhar Mishra (1900-1986) translated Sir Walter Scott's Lady of the Lake into Odia as Sarasundaree and Ajaya Chandra Das translated Scott's The Lady of the Last Minstrel. Chandramani Das translated Goldsmith's The Deserted Village and Govinda Tripathy translated Cervantes's Don Quixote.

Translation was not limited to Kalidas's writing; it was also happening with the Srimad Bhagabat Gita and many other Sanskrit mythologies. Baisnav Charan Das (1890-1961) translated Lingapurana and Brahmapurana into Odia. Chintamani Acharya (1891-1957) translated the Srimad Bhagabat Gita by following both the Sanskrit and Jagannath Das's Srimad Bhagavata. Translation of Sanskrit classics in various styles was going on. The translator was not always following the style of the source text. 
Gopinath Singdeo (1893-1956) did poetry translation of Naisadha, Kumarasambhaba, Raghubamsa, Bhattikabya, Shishupala Badha, Keeraatarjuna in Odia. Likewise, Harapriya Devi (1915-), famous as a renowned translator, translated the Srimad Bhagabat Gita poetically.

During this period, there emerged a group of women translators in Odisha. They were popular as creative writers and they have contributed much to the Odia literature through translation. Narmada Kar (1893-1963) and Prativa Kar (18981951)translated many stories from foreign languages to Odia, Sulochana Dei (1895-1947) imitated Kalidas's Nalodaya in her Damayantee in Odia and translated five Shakespearean plays into Odia (it was a sense to sense translation),Vanalata Dei translated Kalidas's Nalodaya and named it Nishidharaaja in Odia.

\subsection{Translation in Pragatibaadee Period (1935-1947)}

There were many sociopolitical events during this period which influenced Odia literature. It was the influential time of Marx, Gandhi and other revolutionary leaders. India was moving towards independence. There was the disastrous impact of the Second World War. Autocracy had already been discarded and democracy was being established. Middle class already became the dominant class. The aim of the writers of this period was to awaken the exploited and poor people. At this period, Bhagabaticharan Panigrahi formed the Utkala Communist Party and resigned from the Congress Socialist Party. Chintamani Mishra (1904-1980) translated Mahatma Gandhi Jeebani, Hindu Dharmara Jaati O Taara Gati and Aama Durgatira Dina.

During this period, translation was happening not only from English to Odia, but also from Odia to English. Ganesh Prasad Singhdeo translated Brajanath Badjena's Samara Taranga into English as War Waves. Harendranath Chottopadhyaya translated Sachi Routray's Baajirout O Anyaanya Chaalishiti Kavitaa into English as The Boatman Boy and Forty Poems. Kunjabihari Nayak(1918-) translated Radhanath's Chilika and Gopabandhu's 
Translation in Odia: A Historical Survey

Bandeera Aatmakathaa into English lyrical poetry.

One could get translation in early 20th century not only from English, Sanskrit and Bangla to Odia but also from Tamil to Odia. Nityananda Mohapatra translated Kamba Ramayanam into Odia. He also translated Ramana Maharshee, Swarajya Sanghitaa into Odia.

\section{Modern Age (20 $0^{\text {th }}$ to $21^{\text {st }}$ century)}

Government initiatives for the promotion of translation activities started in mid- $20^{\text {th }}$ century. Various national institutions and state institutions were established to encourage and promote translation activities. Commission for Scientific and Technical Terminology (CSTT), Sahitya Akademi, National Book Trust (NBT) and many state organizations were established to work for translation. Odisha became a state in 1936. Odisha Sahitya Academy was established in 1957. It has been one of their mandates to encourage translation from different Indian languages and foreign languages to Odia and vice versa. Officially making translation as a mandate of an institution accelerated translation work into Odia. Sahitya Akademi instituted translation award in 1989. From 1989, it has been selecting the best translation in regional languages of India and conferring the award. Odisha State Bureau of Textbook Preparation and Production (OSTB) was established in 1970 by the government of Odisha to prepare and promote textbooks in Odia. It has been publishing Odia translations of many classics and fundamental books from many subjects. During this period, the Odia translation of books from other subjects which are non-literary in nature took place and OSTB played a key role here. It is not that non-literary translations were published by government organization only, there were private publishers like Cuttack Trading Co who were publishing science translation.

Mid-20 th century and the last decade of $20^{\text {th }}$ century witnessed a new trend of translation emerging in Odisha. Masterpieces of Odia literature started getting translated into 
English. Towards this enterprise, publisher like Four Corners, Grassroots, Oxford University Press started publication of English translation in $20^{\text {th }}$ century. Kalindi Charan Panigrahi's Matira Manisha was translated by Lila Ray into English as A House Undivided that was published in 1973 by Four Corners. Grassroots has already published the Odia classics in English right from Fakir Mohan Senapati's works. Oxford University Press published Gopinath Mohanty's Paraja in English translated by B.K. Das. Chandrasekhar Rath's Yantrarudha was translated into English by Jatindra Kumar Nayak as Astride the Wheel which was published by OUP in 2003. University of California Press published Six Acres and $a$ Third in 2005 which was an English translation of the Odia classic, Chhamaana Aathaguntha by Fakir Mohan Senapati. It was translated by Rabi Shankar Mishra, Satya P. Mohanty, Jatindra N. Nayak, Paul St.-Pierre. In $21^{\text {st }}$ century, there came another publisher named Rupantara who also started publishing English translation of the Odia classics. Rupantara's translations are of non-fiction genre.

Post-independent Odia literary translation is a period where T.S. Eliot's writings influenced many Odia writers to bring a new style and a new theme to Odia literature through translation. Guru Prasad Mohanty wrote Kalapurusha in Odia following T.S. Eliot's The Wasteland. Bhanuji Rao was also influenced by T.S. Eliot's writings. Post-independent Odia writers started using free style. Most of their poetry is in free verse with myths and symbols. Some of these writers are Ramakanta Rath, Sitakant Mahapatra, Soubhagya Kumar Mishra, Rajendra kishore Panda,Prativa Satpathy,Mamata Dash, Haraprasad Das.

Ananta Charan Sukla, a renowned professor of English and Comparative Literature who did his research on the concept of imitation in Greek and Indian Aesthetics, translated four Greek dramas, namely Prometheus Bound (Aeschylus), Oedipus the King (Sophocles), Medea (Euripides) and The Frogs (Aristophanes). These Odia translations were staged in various colleges and universities of Odisha. His translation of Aristotle's Poetics into 
Odia as Aristotlenka Kabya Tatwa with commentary and notes which was published in $60 \mathrm{~s}$ is an outstanding translation. Many of Tagore's lyrics have been translated into Odia by him which is available in CD form also (sung by Trupti Panda).

In 70s and 80s, there was a group of Odia writers who were writing Odia fiction where individual became the protagonist. Some of them are the famous established Odia authors. They are Gopinath Mohanty, Surendra Mohanty and Manoj Das. Gopinath Mohanty translated Tolstoy's War and Peace (Yudhya O Shanti) in three volumes (published in 90s) and Tagore's Jogajog (published in 70s) into Odia. Gopinath Mohanty's Paraja, Danapani, Laya Bilaya were translated into English by B.K Das. Danapani was translated as The Survivor in English by B.K Das, was published by Macmillan India Limited in 1995. Lark Books published the English translation of Laya Bilaya as High Tide, Ebb Tide by B.K Das. Sahitya Akademi published the English translation of Dadi Budha as The Ancestor by Arun Kumar Mohanty.

Translation of science fiction emerged in mid- $20^{\text {th }}$ century. Godabarisha Mishra, a noted Odia writer, educationist wrote two science fiction around 1950. He wrote Ghatantara being inspired by R.L. Stevenson's Strange Case of Dr Jekyll and Mr Hyde and also wrote Nirbaasitaa. Other popular science book like Stephen Hawking's A Brief History of Time has been translated in Odia by Sri Batsa Nanda in early $21^{\text {st }}$ century.

Odisha State Bureau of Textbook Preparation and Production published translations of many fundamental subject specific books in 80s and 90s. Plato's Republic was translated into Odia by Ganeswar Mishra and published by OSTB in 1974. He also translated A.J Ayer's The Problem of Knowledge into Odia which was published by OSTB in 1977. The classic book of P.H. Nowell Smith, entitled, Ethics was translated into Odia by N.Durzie and published in 1976 by OSTB. C.K.Ogden and I.A. Richard's Meaning of Meaning was translated by Nityananda Durzie and published by OSTB in 1980. 
Knowledge Text Translation published by OSTB in $20^{\text {th }}$

\begin{tabular}{|c|c|c|}
\hline Subject & Title & Translation \\
\hline Physics & $\begin{array}{l}\text { F.A. Jenkins } \\
\text { and H.E. White's } \\
\text { Fundamental } \\
\text { of Optics }\end{array}$ & $\begin{array}{l}\text { Moulika Aaloka } \\
\text { Bingyaana by } \\
\text { B.S. Mohanty }\end{array}$ \\
\hline Physics & $\begin{array}{l}\text { Fundamentals } \\
\text { of Physics } \\
\text { by Halliday } \\
\text { and Resnick }\end{array}$ & $\begin{array}{l}\text { Padaartha } \\
\text { Bingyaana by } \\
\text { H.Mishra }\end{array}$ \\
\hline Physics & $\begin{array}{l}\text { R.L. Weber, } \\
\text { K.V. Manning, } \\
\text { M.W. White's } \\
\text { College Physics }\end{array}$ & $\begin{array}{l}\text { Mahavidyalaya } \\
\text { Padartha } \\
\text { Bingyaana by } \\
\text { H.K. Pattanaik }\end{array}$ \\
\hline Education & $\begin{array}{l}\text { Modern } \\
\text { Philosophy of } \\
\text { Education by } \\
\text { J.S. Brubacher }\end{array}$ & $\begin{array}{l}\text { Aadhunika } \\
\text { Sikhyaa } \\
\text { Darshana } \\
\text { by S. Nath }\end{array}$ \\
\hline Anthropology & $\begin{array}{l}\text { Structure and } \\
\text { Function in Primitive } \\
\text { Society by A.R. } \\
\text { Radcliff Brown }\end{array}$ & $\begin{array}{l}\text { Aadima } \\
\text { Samaajara } \\
\text { Swarupa O } \\
\text { Prakaarjya by } \\
\text { M.M. Mohapatra }\end{array}$ \\
\hline Economics & $\begin{array}{l}\text { International } \\
\text { Economics by } \\
\text { C.P. Kindeberger, } \\
\text { Foundations } \\
\text { of Economics } \\
\text { by Silverman, } \\
\text { EA.G.Robinson's } \\
\text { Monopoly has been } \\
\text { translated by B.K. Bal as } \\
\text { Ekaadhikaara in Odia, }\end{array}$ & \\
\hline
\end{tabular}


Translation in Odia: A Historical Survey

$\begin{array}{lll}\text { Mathematics } & \text { R.J.T. Bell's An } & \text { Trimaatrika } \\ & \text { Elementary } & \text { Sthaananka } \\ & \text { Treatise on } & \text { Jyaamiti by } \\ & \text { Coordinate } & \text { N.Tripathy } \\ & \text { Geometry of } & \\ & \text { Three Dimensions } & \end{array}$

Mathematics

E.Askwith's

Shankuchhedara

Bislesanaatmaka

Jyamiti by S.C Das

Botany

A.W. Glaston's Life

Sabuja Paadapa

Processes in Plants

Jibana by

B.B.Padhi

Botany

Cari's The Cell

Kosha by

B.Samantrai

\begin{tabular}{lll} 
Political Science & $\begin{array}{l}\text { Ivor Jennings' } \\
\text { The Queen's } \\
\text { Government }\end{array}$ & $\begin{array}{l}\text { Raaninka } \\
\text { Shaasana by S. } \\
\text { Dash }\end{array}$ \\
\hline Political Science & $\begin{array}{l}\text { Machiavelli's the } \\
\text { Prince }\end{array}$ & $\begin{array}{l}\text { Narapati by S.C. } \\
\text { Das }\end{array}$ \\
\hline \multirow{2}{*}{ Aesthetics } & $\begin{array}{l}\text { Edmund Burke's A } \\
\text { Philosophical Enquiry } \\
\text { into the Origin of Our } \\
\text { Ideas of the Sublime } \\
\text { and Beautiful, a } \\
\text { treatise on aesthetics }\end{array}$ & $\begin{array}{l}\text { Mahaan O } \\
\text { Sundara } \\
\text { Dhaaranaara } \\
\text { Mulautsa } \\
\text { Eka Taatwika } \\
\text { Jingyaasaa by S.N. } \\
\text { Barik }\end{array}$ \\
\hline Geology & $\begin{array}{l}\text { L.G. Berry and Brian } \\
\text { Mason's Mineralogy }\end{array}$ & $\begin{array}{l}\text { Khanija } \\
\text { Bingyaana Tattwa } \\
\text { by M.N. Satapathy }\end{array}$ \\
\hline \multirow{2}{*}{ Geology } & $\begin{array}{l}\text { F.H.Lahee's Field } \\
\text { Geology }\end{array}$ & $\begin{array}{l}\text { Khetra } \\
\text { Bhubingyana by } \\
\text { B.Dash }\end{array}$ \\
& &
\end{tabular}


Along with the Knowledge Text translation, OSTB has also published literary translation. A Berriedale Keith's A History of Sanskrit Literature has been translated by B.Kar into Odia as Sanskruta Saahityara Itihaasa. Nathaniel Hawthorne's The Scarlet Letter was translated by Gadadhar Mishra as Lohita Akhyara which was published in 1989 by OSTB.

Shakespeare and Kalidas have been influencing throughout the 20th century. Mayadhar Mansingh (1905-1973), an outstanding Odia writer who did his Ph.D on a comparative study of William Shakespeare and Kalidas from Durham University. He is famous for his translation of Shakespearean plays into Odia. He translated Macbeth into Odia in 1960. Towards mid-20 ${ }^{\text {th }}$ century, Akshaya Kumar Chakravarti and Mayadhar Mansingh introduced the works of Shakespeare to Odia audiences; indeed, Chakravarti's Hamlet and Mansingh's Othello stand out as brilliant pieces of translation (Pattanaik, 2000). Basant Kumar Satpathy translated Charles and Mary Lamb's Tales from Shakespeare. Pranatha Mohanty (1907-1991) translated Kalidas's Rutusanghaara, Meghadutam and Kumarasambhabam into Odia.

The influence of Gandhi and Vinoba continued in this period. Their works were being translated into Odia. Annapurna Maharana translated Vinoba's Geeta Pravachane, Gandhi's Buniyadee Sikhyaa, Narahari Parikha's Taruneekanya Prati and Stree Purusha Maryaadaa into Odia.

Translating children's literature emerged as a new genre in Odia. Udayanath Sarangi (1905-1999) is a popular writer for children literature in Odia. He translated the American author Harriet Beecher Stowe's Uncle Tom's Cabin into Odia. He named it as Tomkaakaanka Kuteera. Ramkrushna Nanda translated Upendra Kishore Roy Chowdhury's Tuntunir Boi from Bangla to Odia. Raghunath Das (1914-1984) translated Alice in Wonderland as Ajabadeshare Alice into Odia.

Fitgerald's The Rubaiyat of Omar Khayyam is a classic in the field of translated literature in English and it has been hugely 
translated into most of the world's languages. It was translated into Odia in $20^{\text {th }}$ century. Ananta Prasad Panda translated selected poems of Omar Khayyam and named it Omar Chayanika. There was another famous translator named Gopalchandra Kanungo who also translated Edward FitzGerald's The Rubáiyát of Omar Khayyám into Odia.

$20^{\text {th }}$ century Odia translation could also witness the voice of social reformation and revolution against the capitalist attitude. The October Revolution of Russia had a far reaching impact and Odia writers were influenced by the revolution. The Odia translation of Gorky's The Mother by Ananta Patnaik could justify the fact stated above. Ananta Patnaik (1912-1987), was a revolutionary Odia poet; he got Soviet and Nehru Award for his Odia translation of Maxim Gorky's The Mother. Apart from this translation, he also translated Bhaagyara Kheea, Sikhyaanibaasa and Manishara Swapna Sata Helaa.

Jnanendra Verma (1916-1990) translated Eliot, Ezra Pound and Walt Whitman's poetry into Odia; Emily Zola's Nana (1880) and Maurice Maeterlinck's Blue Bird (1908) into Odia as Nana Metarlinka Neela Bihanga, Tennyson's Enoch Arden, Kalidas's Meghadutam into Odia. He got award for his translation of Ezra Pound's poetry into Odia.

Among the $20^{\text {th }}$ century influential philosophers, Sri Aurobindo has a remarkable space and he has become an institution through his philosophy and works. $20^{\text {th }}$ century Odia literature is greatly enriched by the translation of Aurobindo's works. Chittaranjan Das, the great educationist, translated Sri Aurobindo's The Human Cycles, Life Divine, Synthesis of Yoga and War and Self-Determination into Odia and also Mother's collected works into Odia. He was associated with two NGOs, namely Sikhyasandhan and Agragaamee. He translated many important books on education into Odia such as Vasily Sukhomlynsky's To Children I Give My Heart translated into Odia as Mo Hrudaya Pilanka Pai, Leo Tolstoy's Yasnaya Polyana and Letters to a Teacher and A.S. Neil's Hearts Not Heads in the School translated into Odia as 
Jane Sikhakanku Chithi and Bidyalayare Mastika Nuhe Hrudaya. In the last two decades of his life he had contributed to the field of Odia literature and education much through translation. He is an outstanding translator who has strengthened Odia literature through translation in $90 \mathrm{~s}$ and in the last decade of $20^{\text {th }}$ century. He translated Etienne De La Boitie's on The Discourse of Voluntary Servitude into Odia as Agya Palanara Rajaniti and Kakuzo Ozakura's The Book of Tea into Odia as Chaahaara Kahani. Chaahaara Kahani can be considered as a transcreation as he brings many comparisons between having tea in Japan and having tea in India. In Japan, having a cup of tea means one has to be alone and in India it means togetherness. Antoine de Saint-Exupery's The Wisdom of Sands translated into Odia as Saudha Sandesha, Barrows Dunham's Man Against Myth translated into Odia as Mithya Birudhare Manisha and Ananda K. Koomaraswamy's Living Thoughts of Gotama The Buddha translated into Odia as Gautama Buddhanka Amara Bicharachaya. He has also translated nobel prize winning novels into Odia; Karl Gjellerup's Pilgrim Kamanita, Wladyslaw Stanislaw Reymont's novel The Peasants as Chashi. Translated Ivan Turgenev's Rudin in Odia . He translated Iswara Chandra Vidyasagar and Tagore into Odia. Selected poems of R.N. Tagore have been translated by him as Rabindra Katipaya. Tagore's Education: The Religion of Man was translated by him as Siksha: Manushyara Dharma in Odia. Some of Tagore's novels are also enlisted in his huge work of translation. His other translation works in Odia include: Boris Pasternak's Doctor Zhivago, Francois Mauriac's Galigai as Sammohini, Antoine de Saint-Exupery's Little Prince as Rajkumar, Khalil Gibran's Prophet as Mahabanab, Ashapurna Devi's novel Prathama Pratishuti in Odia. He is the skilled translator without having any formal degree on translation who has translated works from many disciplines. Amit Bhaduri's Development with Dignity was translated by him as Sammanara Saha Vikasha and Harsh Mander's Unheard Voices as Kehi Suni Nahanti in Odia. From all his translations, one could state that he has contributed to the field of literary translation as much as to the field of Knowledge Text translation. 
Sikhya Sandhan, a voluntary organization, has been publishing seminal educational books in Odia through translation. It has published Vasily Sukhomlynsky's To Children I Give My Heart translated into Odia as Mo Hrudaya Pilanka Pai by Chittaranjan Das, Tolstoy's Letters to a Teacher and A.S. Neil's Hearts Not Heads in the School translated into Oriya as Jane Sikhakanku Chithi and Bidyalayare Mastika Nuhe Hrudaya by Chittaranjan Das,Sikhya/ Manusyara Dharma Original by Rabindranath Tagore, Translated by Chittaranjan Das John Holt's How do the children learn? translated into Odia by Sumitra Chadhuri, Vasil Sukhamnilasky's Educational Judgement (Sikhya Bichara), translated by Anil Pradhan \& Prafulla Behera, Vinoba Bhabe's Ahinsara anwesana translated into Odia by Shanti Devi.

Grassroots, a publishing house, has a good deal of English translation of Odia classics. It includes: Fakir Mohan Senapati stories translated by Paul-St.Pierre, Leelavati Mohapatra and K.K Mohapatra, published in 2003. Sachidanand Raut Roy stories translated by Paul-St.Pierre, Leelavati Mohapatra and K.K. Mohapatra, published in 2003. The same group of translators translated Santanu Kumar Acharya stories, Kishoricharan Das stories, Gopinath Mohanty stories, Chandrasekhar Rath stories into English. Embers and Ashes: Odia stories of matrimonial blues and bruises was an anthology of stories translated by Paul-St. Pierre, Leelavati Mohapatra and K.K. Mohapatra and published by Grassroots in 2007. Laxmikanta Mohapatra's Kanamamu was translated into English as Uncle One Eye by the same group of translators, published by Grassroots in 2008.

Thomas Carlyle's The Hero and Hero Worship was translated into Odia by Amar Ballav Dey. Lala Nagendra Ray's translation of Melville's Moby Dick, Krushna Mohan Mohanty's translation of The Prisoner of Zenda, Subodh Chatterjee's translation of Richardson's Pamela, Panchanan Pati's Bram Stoker's Dracula, Ghanashyam Samal, Bansidhar Das translated Stevenson's Treasure Island and some of Jule Verne's works, Pravash Satpathy translated Crime and Punishment in Odia. Shakuntala Baliarsingh translated 
Thomas Hardy's novels into Odia. Prativa Satapathy is a famous writer in $20^{\text {th }}$ century Odia literature who has translated many world classics into Odia. Pratibha Satapathy got Sahitya Akademi Award in 2001. Under the translation scheme of Central Sahitya Akademy, she translated Kalhana Charita and Nagara Manthan. Under the National Book Trust translation scheme, she translated Subramanium Bharati. Other than her translation works under such government schemes, she translated Pearl S. Buck's The Hidden Flower into Odia as Arana Swapnara Rati, published by Prachi Sahitya Pratisthan in 2004. Isaac B. Singer's The Slave was translated by her as Kritadas in Odia. Chinghiz Aitmatov's The Crane Fly Early was rendered into Odia by Satapathy as Sahasara Shikha and Latvian poetry by Maris Caklais \& Raison into Odia as Bhinna Deshira Muhan. Apart from Tagore's popular fiction and short stories, his Gitanjali had a huge readership in Odia. Tagore's Gitanjali was translated into Odia by the Sahitya Academi Award winner, the famous Odia writer, Hara Prasad Das.

Holocaust literature has also influenced many Odia writers who brought the feel of holocaust to Odisha through translation. Holocaust refers to the mass genocide of the Jews from 1941 to 1945 by the Nazi regime. Elie Wisel's Night, Jona Oberski's Childhood and Graham Greene's The Tenth Man are the famous novels on holocaust experience. Jona Oberski, a Dutch writer, wrote about his holocaust experience in his famous Dutch writing, Kinderjaren in 1978. Ralph Manheim translated this into English in 1983. Mausumi Acharya, a professor in Psychology, translated the same English into Odia as Pilaadina which was published in 2000. Elie Wisel records his experience in the Nazi Germany concentration camp in his writing, Night. Graham Greene's The Tenth Man is another famous writing on the same. Mausumi Acharya has translated all these three important novels into Odia on holocaust reality at the turn of the 20th century.

Sahitya Academi and National Book Trust have a long list of Odia translations that one can get from their catalogues. Private Publisher like New Age Publication (AK Mishra Publication), Friends 
Publisher, Vidyapuri, Orient Blackswan have been publishing Odia translation. National Translation Mission is another government of India scheme to make knowledge texts available in Odia through translation. It has already published Romila Thapar's Early India : From the Origins to AD 1300 and Hiriyanna's Outlines of Indian Philosophy in Odia.

\section{Conclusion:}

History of Odia translation is not a homogeneous entity. In early days, texts were translated or transcreated into Odia from Sanskrit. The skopos of early translation was to make knowledge accessible and available to the people. It was a strong weapon to fight against the Brahminical attitude. Medieval period was a continuation of the same tradition. Texts were of religious, mythological and astronomical nature. From $19^{\text {th }}$ century onwards, English became the dominant language and translation was going on from English to Odia which is a tradition still continues. Translation was a tool to establish Odia as an independent language. In early $20^{\text {th }}$ century, translation was to empower women which could be witnessed from the translators of Satyabadi period. Non-literary translation took place visibly from $60 \mathrm{~s}$ and $70 \mathrm{~s}$ onwards. Post-independent era witnessed the institutionalization of translation by various government institutions like OSTB (for non-literary translation), Sahitya Academi and National Book Trust. From 80s onwards, a new trend of translation from Odia to English took place. There were women translators who translated Shakespeare's plays and Kalidas's plays in to Odia. Odia translation of four major Greek plays was a huge success and these plays were staged in many colleges and universities in Odisha. Science fiction, holocaust literature, popular science books, religious books from major religions were translated by both govt and nongovt organization. Recently, National Translation Mission started bringing out non-literary translation (Knowledge Text translation) in Odia. 


\section{REFERENCES:}

Chaini,Ratnakar. 1984. Viveki (Oriya), Cuttack

Choudhury, Janmejaya. 2013. Growth of Printing Presses and Periodicals: A Mouthpiece of National Consciousness, Odisha Review

Cushman, Stephen, Cavanagh,Clare, Ramazani,Jahan, Rouze, Paul, eds. 2012. The Princeton Encyclopedia of Poetry and Poetics, Princeton University Press

Das, Satyabrata, Sahoo. U.N, 2009. The Contemporary Relevance of Sri Jagannath Dasa's Srimad Bhagavata in Oriya, Odisha Review

Datta, Amaresh, 1988. Encyclopedia of Indian Literature, Volume 2, Sahitya Akademi

Dipti, Ray. 2007. Prataparudradeva : The Last Great Suryavamsi King of Orissa (AD 1497 TO AD 1540), Northern Book Centre: New Delhi,.

Encyclopedia of Indian Literature, 1988.Sahitya Akademi,

Kar, Bauribandhu. 1998. Odia Sahityara Itihasa. Friends' Publishers: Cuttack

Mohanty, Debendra. 1995. Panchasakhaa Odia Sahitya. Friends' Publishers: Cuttack

Mohanty, Sachidanandan, ed. 2005. Early Women's Writings in Orissa, 1898-1950 A Lost Tradition, Sage Publication

Mohapatra, Ashok K, 2011. Appropriation, Coloniality and Ethics of Translation: Madhusudan Rao's Nirbasitara Bilapa and William Cowper's The Solitude of Alexander Selkirk in Dipti Ranjan Pattanaik edited Ravenshaw Journal of Literary and Cultural Studies, Ravenshaw University, Vol:1, Issue: 01

Moharana, Surendra Kumar. 2001. Odia Sahityara Itihas. Orissa Book Store: Cuttack

Patnaik, B.N., 2012. Introducing Saraladas Mahabharata, Central 
Translation in Odia: A Historical Survey

Institute of Indian Languages, Mysore

Pattanaik, Diptiranjan, 2002. The Power of Translation: A Survey of Translation in Orissa in Simon, Sherry, and Paul St-Pierre.edited Changing the terms: Translating in the postcolonial era. Orient Blackswan

Samal, J.K, Nayak, P.K., 1993. Makers of Modern Orissa, Shakti Malik Abhinav Publications

Simon, Sherry, and Paul St-Pierre. Eds. 2002. Changing the terms: Translating in the postcolonial era. Orient Blackswan.

Simon, Sherry, Pierre, Paul St. eds. 2000. Changing the Terms: Translation in the Postcolonial Era. University of Ottawa Press: Ottawa

St-Pierre,Paul, Kar, Prafulla C.eds. 2007. Translation: Reflections, Refractions, Transformations, John Benjamins Publishing Company

The Baptist Magazine, 1839. Oxford University Press. 